\title{
What is a Population in Online Shopping Research? A perspective from Malaysia
}

\section{${ }^{1}$ Roszi Naszariah Nasni Naseri, ${ }^{2}$ Harniyati Hussin, ${ }^{3}$ Maryam Mohd Esa, ${ }^{4}$ Noorizda Emellia Mohd Aziz, ${ }^{5}$ Mohd Norazmi bin Nordin}

\author{
${ }^{1}$ Faculty of Technology Management \& Technopreneurship, Universiti Teknikal Malaysia Melaka, and \\ Universiti Teknologi MARA Melaka. Email: roszinasni@gmail.com \\ ${ }^{2}$ Universiti Teknologi MARA Melaka \\ ${ }^{3}$ Kolej Universiti Islam Melaka, Malaysia. Email: maryam@kuim.edu.my \\ ${ }^{4}$ Kolej Universiti Islam Melaka, Malaysia. Email: noorizda_emellia@kuim.edu.my \\ ${ }^{5}$ Open University Malaysia. norazminordin@ oum.edu.my
}

Article History: Received:11 January 2021; Accepted: 27 February 2021; Published online: 5 April 2021

\begin{abstract}
The rise of internet usage worldwide has created a new phenomenon of consumer behaviour, in which the consumers' attention has been shifted to online purchasing. The increase confidence in technology and online payment sectors are causing a change in consumer behaviour, away from traditional methods (Khouloud, 2020). Statista (2018) reported an estimated amount of 1.8 billion people worldwide now purchase their goods online. According to the Internet World Statistics (2020), there are over 3 billion internet users globally, thus representing a $577 \%$ increase in growth when compared to the global population of internet users in 2000. This trend indicates that online shopping has a lot of potential and benefits to societies and businesses worldwide. The purpose of this paper is to analyse the best population in online shopping research for Malaysia context.
\end{abstract}

Keywords: Population, Online Purchase Intention, Malaysia.

\section{Introduction}

Many traditional consumer-oriented businesses and start-up projects alike have been gradually shifting away from business models that are shop-based, to those that are virtually borderless and customer-centric. According to John and Wichayachakorn (2019), the most crucial factor that influences online shopping is convenience. Hence, with the rise of internet usage, the convenience offered by the internet has led many companies to use online advertising as an essential tool to provide information, create brand awareness, and influence customer perception and attitudes (Duffett, 2017).

In Malaysia, online purchasing is showing encouraging progress among consumers. According to Simon and Sarah (2019), 80 per cent of Malaysian purchase products or services online. The convenient side of online shopping such as practicality has strengthened buyers' intention to make online purchases (Ratih et al., 2020). Apart form that, online shopping activity can also reduce time and energy compared to going shopping the conventional way. Based on the findings by the Malaysian Communications and Multimedia Commission (2018), the adoption rate of e-commerce mainly comprise individuals aged between 20 to 30 years old. This finding is consistent with the results of the EcInsider (2019) which also stated that the majority of the online consumers belong to this age group.

As there are many benefits of online shopping such as convenience, time saving and ability to boost the economic sector, various initiatives and programmes in Malaysia are carried out by the government to promote e-commerce in order to encourage and provide confidence in Malaysian buyers to purchase online. One of the role played by the industries is to make the digital platform tangible to achieve the aim for Malaysian businesses to move towards digitisation (Malaysia Digital Economy Corporation, 2020). Various technological developments have improved customers' intention to purchase via the internet as many products are now available online. Therefore, this study aims to define the population used in online shopping study.

\section{Target Population}

Target Population refers to the entire group of people, events, or things of interest that the researcher wishes to investigate (Sekaran and Bougie, 2006). In many academic studies, due to practical considerations such as convenience and, time and cost-saving, college or undergraduate students are often used as research subjects (Zikmund and Babin, 2006). There is no exception for the online shopping, in which quite a number of studies have employed undergraduate and postgraduate students as the research subject instead of the real customers (Sorce et al. 2005; Cyr et al. 2008; Butt et al. 2016). Though students can appropriately represent the household consumers, most of the time, they do not provide sufficient external validity to represent the consumer as the student population is likely to be atypical (Zikmund and Babin, 2006). It is, therefore, suggested that data for online shopping study is collected from real customers. 
The online shopping emphasizes on a specific quality target group with relevant experience and knowledge. Therefore, purposive sampling method is the best technique to be implemented (Sekaran and Bougie, 2010). Most importantly, other similar research had also utilised the purposive sampling technique for online shopping studies namely Mahliza (2020), as well as Roy, Basu and Ray (2020).

In short, according to Etikan et al. (2016), purposive sampling technique allows researcher to decide what needs to be known and sets out to find people who can and are willing to provide the information by virtue of knowledge or experience. Evidently, this method is also used in quantitative research to identify and select the information-rich cases for the most proper utilisation of available resources (Olsen, Vogt and Andereck, 2018). Thus, this method is the most appropriate in choosing the responds for online shopping study. Therefore, for online shopping study, the criteria of the respondents are:

Firstly, Euromonitor International (2011) identifies all living human as a customer of a product and brand. Despite incorporating online shoppers from all age groups, the statistics released by EcInsider (2019) have focused on general customers that range young customers from the age of 18 to 24 years old, and $25-34$ years old as well as 35 to 44 years old, 45 to 54 and 56 to 64 years old. Thus, coupled with the fact that customers in the age of 18 and above can have steady income and able to decide on their purchase (Euromonitor International, 2011), it would be appropriate for online shopping study to consider online shoppers aged 18 years old and older as a sample.

As to ensure a valid and reliable evaluation from the customers, it would be more appropriate for online shopping study to consider only the existing customers who have adequate experience with buying products through online shopping website (Awad and Ragowsky, 2008; Al-Debei et al. 2015; Chin and Goh, 2017; Raman, 2019). Thus, consistent with many of the previous studies that set six months to qualify for the customers to evaluate their attitudes and behaviours (Han et al. 2009; Han and Kim, 2010; Kilger and Romer, 2007), the respondents of online shopping study should also fixed to customers who have been using the online shopping platforms to purchase any products for at least six months.

\section{Conclusion}

This study is to examine and understand the characteristics of current users of online shopping which aims to define the population used in online shopping study. Despite the high potential growth of retail e-commerce and the continued interest in online shopping in Malaysia, there is still a lack of understanding about the characteristics of online shoppers in Malaysia and how this will affect consumer marketing. Today, online shopping has become a dominant alternative shopping platform that would be difficult for conventional retailing to compete with. However, this platform can be considered risky for those who have never done any online shopping before. As a result, novice consumers with little to no online shopping experience are more risk-averse than their more experienced counterparts. There is a plethora of variables that may constitute that related, and shape people's attitudes and behaviour. For example; Liu et al. (2020) revealed in their studies that customers with a lower transactional frequency are more likely to search for functionality that can assist with initial adoptions when assessing an e-commerce site's functional efficiency in order to reduce possible risks. When learning to transact on an e-commerce platform, functionalities such as consultation and guidance, caretaking and safekeeping, and hospitality can appeal to inexperienced consumers. These features are crucial for easing beginners into online transactions by assisting them in overcoming challenges created by their lack of experience. Besides, Sohn (2017) believed consumers' perceptions of technology usefulness play a critical role in determining their intentions for and use of online shopping. In another research setting, mobile device-based online purchases can increase consumers' overall online purchases (Huang et al., 2016; Wang et al., 2015); however, little is known about mobile online shopping in general (Hew, 2017), and consumer adoption in particular. Understanding people's attitudes and behaviour will assist e-marketers and businesspeople in better insight how they can increase revenue via online shopping while providing greater profitability for shareholders. The ubiquity of the Internet allows information to be sent globally. Due to double-digit worldwide growth in revenue (15\%) and orders (13\%) (eMarketer, 2018) in all forms of online shopping platform, such as businessto-business (B2B), business-to-consumer (B2C), and business-to-government (B2G), e-commerce accounted for around 2.29 trillion dollars globally (John, 2018) and is predicted to hit 4 trillion dollars by 2020 (eMarketer, 2016) (Rahman et al., 2018).

\section{Acknowledgement}

The researcher would like to thank the Faculty of Technology Management and Technopreneurship (FPTT), Universiti Teknikal Malaysia Melaka and Universiti Teknologi MARA Melaka for the opportunity given to run this study. 


\section{References}

1. Awad, N. F. and Ragowsky, A., 2008. Establishing trust in electronic commerce through online word of mouth: An examination across genders. Journal of Management Information Systems, 24(4), pp. 101-121.

2. Al-Debei, M. M., Akroush, M. N. and Ashouri, M. I., 2015. Consumer attitudes towards

3. online shopping. Internet Research, 25(5), pp. 707-733.

4. AR Abdul Razzaq, KH Tan, MZ Mustafa, N Bokhari. (2017). The Secret to A Successful Homestay Development: Lesson from Miso Walai Homestay (MWH) Kinabatangan Sabah, Malaysia. Pertanika Journal of Social Sciences \& Humanities, 2017.

5. Butt, I., Tabassam, S., Chaudhry, N. G. and Nusair, K., 2016. Using technology acceptance model to study adoption of online shopping in an emerging economy. The Journal of Internet Banking and Commerce, 21(2).

6. Chin, S. L. and Goh, Y. N., 2017. Consumer purchase intention toward online grocery shopping: View from Malaysia. Global Business and Management Research, 9(4s), pp. 221238.

7. Cyr, D., Kindra, G. S. and Dash, S., 2008. Web site design, trust, satisfaction and e-loyalty: The Indian experience. Online Information Review, 32(6), pp. 773-790.

8. Duffett, R. G., 2017. Influence of social media marketing communications on young consumers' attitudes. Young Consumers, 18(1), pp. 19-39.

9. EcInsider, 2019. Malaysia's online shopping behavior in infographic. [online] Available at: www.ecinsider.my/2019/03/malaysia-online-shopping-behavior-infographic-html?

10. eMarketer. (2016). Worldwide retail ecommerce sales will reach $\$ 1.915$ trillion this year. Retrieved from https://www.emarketer.com/Article/ Worldwide-Retail-Ecommerce-SalesWill-Reach- 1915-trillion-This-Year/1014369.

11. eMarketer. (2018). Retail ecommerce performance metrics. Retrieved from; https://www. emarketer.com/performance/channel/58fe $47 \mathrm{a} 2$ d2670009840a9ec7/58dd63dd2357af0c900b4d33.

12. Etikan, I., Musa, S.A. and Alkassim, R.S., 2016. Comparison of convenience sampling and purposive sampling. American journal of theoretical and applied statistics, 5(1), pp.1-4.

13. Euromonitor International., 2011. Consumer Lifestyles in Malaysia. [online] Available at: http://www.portal.euromonitor.com.eserv.uum.edu.my/Portal/Pages/Magazine/TopicPage.As $\mathrm{px}$

14. Han, H., Back, K. J. and Barrett, B., 2009. Influencing factors on restaurant customers' revisit intention: The roles of emotions and switching barriers. International Journal of Hospitality Management, 28(4), pp. 563-572.

15. Han, H. and Kim, Y., 2010. An investigation of green hotel customers' decision formation: Developing an extended model of the theory of planned behavior. International Journal of Hospitality Management, 29(4), pp. 659-668.

16. Hew, J.-J., 2017. Hall of fame for mobile commerce and its applications. A bibliometric evaluation of a decade and a half (2000-2015). Telemat. Inform. 34 (1), 43-66.

17. Huang, L., Lu, X., Ba, S., 2016. An empirical study of the cross-channel effects between web and mobile shopping channels. Inf. Manag. 53 (2), 265-278.

18. Internet World Statistics, 2020. Internet user's distribution in the world. Internet World Statistics. [online] Available at: www.internetworldstats.com

19. Khouloud, A., 2020. Are we witnessing the awakening of a new world order? Forbes@10. [online] Available at: https://www.forbesmiddleeast.com

20. Kilger, M. and Romer, E., 2007. Do measures of media engagement correlate with product purchase likelihood? Journal of Advertising Research, 47(3), pp. 313325.

21. Liu, F., Lim, E. T. K., Li, H., Tan, C. W., \& Cyr, D. (2020). Disentangling utilitarian and hedonic consumption behavior in online shopping: An expectation disconfirmation $\begin{array}{llll}\text { perspective. Information and Management, } & \text { 57(3), } 103199 .\end{array}$ https://doi.org/10.1016/j.im.2019.103199

22. Mahliza, F., 2020. Consumer Trust in Online Purchase Decision. EPRA International Journal of Multidisciplinary Research (IJMR), 6(2). 
23. Malaysian Communications and Multimedia Commission (MCMC), 2018. e-Commers consumer survey 2018. Malaysian Communications and Multimedia Commission. [online] Available at: http://www.mcmc.gov.my

24. Malaysia Digital Economy Corporation, 2020. Digitilizing SMEs. Malaysia Digital Economy Corporation. [online] Available at: https://mdec.my/digital-economyinitiatives/100-godigital/

25. Mohamad Zaid Mustafa. (2019) Organizational Commitment Survey: A Confirmatory Factorial Analysis Based On Vocational Colleges Teachers Sample, International Journal Of Engineering And Advanced Technology (Ijeat), Published By : Blue Eyes Intelligence Engineering \& Sciences Publication, 5, 279, ISSN:22498958

26. Norazmi, N. (2020). Effect Size for Model of the Influence of Headmasters Leadership on Teacher Task Load and Teacher Job Satisfaction of Special Education Integration Program. International Journal of Phycpsocial Rehabilitation. Vol. 24, Issue 10, 2020: 2102-2112.

27. Norazmi, N. (2020). Factors for the Task Load of Special Education Integration Program (PPKI) Teachers in Johor. International Journal of Innovative Technology and Exploring Engineering (IJITEE), Volume 9, Issue 3: 2413-2416.

28. Norazmi, N., Zaid, M. \& Abdul Rasid, A. R. (2019). The Practice of Headmasters' Leadership and Its Effect on Job Satisfaction of Special Education Integration Program (PPKI) Teachers in Johor, Malaysia. Universal Journal of Educational Research 7.9 (2019): 2008-2014. DOI: 10.13189/ujer.2019.070923.

29. Norazmi, N., Zaid, M. \& Abdul Rasid, A. R. (2020). Relationship between Headmasters' Leadership, Task Load on Special Education Integration Programme Teachers' Job Satisfaction. Universal Journal of Educational Research 8(8):3398-3405

30. Norazmi, N., Zaid, M. \& Abdul Rasid, A. R. (2020). Special Education Integration Program (PPKI) Teachers: Task Load and Job Satisfaction. International Journal of Psychosocial Rehabilitation, Vol. 4, Issue 7: 7439-7445.

31. Olsen, L.M., Vogt, C. and Andereck, K., 2018. Sustaining the common good: tourism professional motives to volunteer for the tourism industry. Tourism Recreation Research, 43(1), pp. 68-81.

32. Raman, P., 2019. Understanding female consumers' intention to shop online. Asia Pacific Journal of Marketing and Logistics.

33. Rahman, M. A., Islam, M. A., Esha, B. H., Sultana, N., \& Chakravorty, S. (2018). Consumer buying behavior towards online shopping: An empirical study on Dhaka city, Bangladesh. Cogent Business and Management, 5(1), 1-22. https://doi.org/10.1080/23311975.2018.1514940

34. Ratih, H., Ana, A, Asnul, D. M. and Thospon, S., 2020. Model of purchase impulsive behaviour of online consumers: Case in Indonesia. International Journal of Advanced Science and Technology, 29(7), pp. 290-298.

35. Roy, G., Basu, R. and Ray, S., 2020. Antecedents of Online Purchase Intention Among Ageing Consumers. Global Business Review, https://doi.org/10.1177/0972150920922010

36. Sekaran, U. and Bougie, R., 2010. Research methods for business: A skill-building approach. 5th ed. West Sussex: John Wiley \& Sons.

37. Simon, K. and Sarah, M., 2019. Digital 2019 spotlight: e-commerce in Malaysia. [online] Available at: www.datareportal.com.reports/digital-2019-ecommerce-in-malaysia

38. Sohn, S. (2017). A contextual perspective on consumers' perceived usefulness: The case of mobile online shopping. Journal of Retailing and Consumer Services, 38(May), 22-33. https://doi.org/10.1016/j.jretconser.2017.05.002

39. Sorce, P., Perotti, V. and Widrick, S., 2005. Attitude and age differences in online buying. International Journal of Retail \& Distribution Management.

40. Wang, R.J.-H., Malthouse, E.C., Krishnamurthi, L., 2015. On the go: how mobile shopping affects customer purchase behavior. Multi-Channel Retail. 91 (2), 217-234.

41. Yogesh Hole et al 2019 J. Phys.: Conf. Ser. 1362012121 
42. Zaid, M., Norazmi, N. \& Abdul Rasid, A. R. (2020). Headmaster Leadership Effect On Task Load Of Special Education Integration Program Teacher. Humanities \& Social Sciences Reviews, Vol. 8 No. 2 (2020): 451-456.

43. Zaid, M., Norazmi, N. \& Abdul Rasid, A. R. (2020). Regression between Headmaster Leadership, Task Load and Job Satisfaction of Special Education Integration Program Teacher. Universal Journal of Educational Research 8.4 (2020) 1356 - 1362. Doi: 10.13189/ujer.2020.080428.

44. Zaid, M., Norazmi, N. \& Abdul Rasid, A. R. (2020). Special Education Intergration Program in Malaysia: Teachers Task Load as Mediator for the Influence of Headmasters Leadership to Teachers Job Satisfaction. Journal of Critical Reviews 7(12): 2763-2768

45. Zaid, M., Norazmi, N. \& Abdul Rasid, A. R. (2020). Structural Equation Modelling Using AMOS: Confirmatory Factor Analysis for Taskload of Special Education Integration Program Teachers. Universal Journal of Educational Research, Vol 8 (Jan, 2020) No 1: 127-133. DOI: 10.13189/ujer.2020.080115. 